Meta

Journal des tradlucteurs

Translators' Journal

\title{
Suppression of References to Sex and Body Functions in the Brazilian and Portuguese Translations of J.D. Salinger's The Catcher in the Rye
}

\section{John Robert Schmitz}

Volume 43, numéro 2, juin 1998

URI : https://id.erudit.org/iderudit/004046ar

DOI : https://doi.org/10.7202/004046ar

Aller au sommaire du numéro

Éditeur(s)

Les Presses de l'Université de Montréal

ISSN

0026-0452 (imprimé)

1492-1421 (numérique)

Découvrir la revue

Citer cet article

Schmitz, J. R. (1998). Suppression of References to Sex and Body Functions in the Brazilian and Portuguese Translations of J.D. Salinger's The Catcher in the Rye. Meta, 43(2), 242-253. https://doi.org/10.7202/004046ar
Résumé de l'article

Par une étude comparée de deux traductions, l'une produite au Brésil, l'autre en Europe, de l'ouvrage célèbre de Salinger, The Catcher in the Rye, publié en 1951 aux États- Unis, l'auteur signale des éléments qui ont été supprimés ou modifiés dans les versions traduites. Il souligne l'importance pour le traducteur de rester fidèle au texte original et d'en respecter l'esprit. 


\title{
SUPPRESSION OF REFERENCES TO SEX AND BODY FUNCTIONS IN THE BRAZILIAN AND PORTUGUESE TRANSLATIONS OF J.D. SALINGER'S THE CATCHER IN THE RYE
}

JOHN ROBERT SCHMITZ

UNICAMP, Campinas, Brazil

\begin{abstract}
Résumé
Par une étude comparée de deux traductions, l'une produite au Brésil, l'autre en Europe, de l'ouvrage célèbre de Salinger, The Catcher in the Rye, publié en 1951 aux ÉtatsUnis, l'auteur signale des éléments qui ont été supprimés ou modifiés dans les versions traduites. Il souligne l'importance pour le traducteur de rester fidèle au texte original et d'en respecter l'esprit.
\end{abstract}

\begin{abstract}
In this comparison of two translations into Portuguese, one Brazilian, the other European, of Salinger's The Catcher in the Rye, an instant success in the United States from its publication in 1951, the author points out translational deviations and freedoms in the translated renditions of this work and stresses the need for translators to be faithful to the original text and not censure the language by "erasing" what they find objectionable.
\end{abstract}

Although J.D. Salinger's The Catcher in the Rye was an instant success in the United States upon its publication in 1951, the novel irritated many American readers at that time. Catcher is the autobiography of a sixteen-year old boy named Holden Caulfield who, after flunking out of his fourth preparatory school, spends an adventurous weekend in New York, "questing after experience and wisdom" (Bryan 1974: 1067), finally ending up in a hospital in a state of depression with the initial stages of tuberculosis as well. Salinger's view of life in American society after the Second World War, with its criticism of materialism and hypocrisy upset many readers. Invectives abound, such as: "He said the army was practically as full of bastards as the Nazis were, if you want to know the truth" (p. 146), "I can't even stand ministers. They sound so phoney when they talk" (p. 105), "All those Ivy League bastards look alike" (p. 90), "The more expensive a school is, the more crooks it has. I'm not kidding" (p. 8), "You don't have to think too hard when you talk to a teacher" (p. 17). ${ }^{2}$ Remarks like these did not endear the novel to certain sectors of American society.

Also, the use of explicit language such as words like turd, goddam, bastard, sonuvabitch, chrissake, and expressions like not to know one's ass from one's elbow, infuriated conservative-minded individuals (Costello 1959: 173). Holden's use of strong language shows his disillusionment with life in general, with his world: "my lousy childhood" (p. 5), "that David Copperfield kind of crap" (p. 5). Rosen (1987: 105) reports that the book was considered to be "dirty" by some readers and downright "immoral" by others. Crusades were spearheaded to remove it from school libraries and from required reading lists in American Literature courses in both secondary schools and universities. Catcher was 
indeed banned from many public and private schools in order to "protect" young people from coming into contact with the critical view of American life and the "unsavory" language used in the novel. But in spite of the criticism and hullabaloo, millions of copies of the book were sold in the USA, in the United Kingdom, and in other English-speaking countries. Translations in numerous languages were also quick to appear.

Portuguese is no exception, for there are two translations of Salinger's masterpiece, one published in Brazil, with numerous editions all bearing the title $O$ Apanhador no Campo de Centeio (The Catcher in the Rye), and another published in Portugal entitled Uma Agulha no Palheiro (A Needle in the Haystack). Chute (1971: 66) has lamented that the names of translators are often omitted from the cover, title page or dust jackets and even in the advertising of translations. He remarks that translations are indeed indispensable but, unfortunately, often unnoticed. Agreeing with Chute (1971: 67) that translators' efforts should be emphasized, I want, at the outset, to mention the names of those who act as a "bridge between cultures and nations", to use Chute's words (p. 66). The Brazilian translators, Álvaro Alencar, Antônio Rocha and Jório Dauster, according to the editor's note, served in the Diplomatic Corps of their country. The translator of the Portuguese version is João Palma-Ferreira. No personal data is provided for this translator.

These four translators are indeed to be commended, for their labors have enabled readers in both Brazil and Portugal who do not read English to enjoy a major work of North American fiction. It is easy to criticize translations, but not at all easy to prepare a translation that will please everyone, especially translation theorists. My critique of the two translations in this paper should not be construed as a denigration of their efforts, but rather as a tribute to the importance of their contribution.

The work of translators is important, no doubt, in all societies. Gress (1971: 57) points out that large numbers of people depend on translations. She remarks that "few readers will get much out the original as they would a good translation" (p. 59).

In a traditional view of translation, the translator is supposed to be faithful to the original. The translator must not make changes or alter in any way the original, which is always considered to be superior to the translation. This is, of course, an ideal, for in practice many translators either intentionally make changes or unconsciously effect changes in their translations. Sabinson (1991) has observed, for example, that two English language translators of the Brazilian novelists, José Lins do Rego and Márcio Souza, have respectively suppressed references to sex and body functions. In a poststructural view of translation, the translator always alters the original and the changes are dictated by the political-social-cultural ideology existing at the time the translation is being prepared. Robinson (1991) argues for a "somatic" approach to translation and states his view in the following words:

If you do not feel the body of the SL text, you will have little chance of generating a physically tangible or emotionally alive TL [target language] text. The TL text you create will read like computer-generated prose: no life, no feeling. (1991: 17)

To compare two different translations of a literary work as The Catcher in the Rye, one can, for example, look at the target language translations of the source language vocabulary and syntax in order to see how each translations "reads". A comparison of the two different renditions of the same work published in two different countries where the same language is spoken may afford the student of translation an excellent opportunity to predict how the novel has been received in each nation. Different translations of a specific novel, play or poem may show that there are different ways of rendering a translation. What is most likely a felicitous choice of vocabulary for one nation is not at all successful for another. Differences in syntax may show that the respective translators are "speaking" to their particular community. 
But there are more revealing ways of examining two different translations of a literary work. One can study the different scenes or "moments" in the source language and see how each translator renders them in the target language. Are the scenes or episodes presented in the target language as they are in the original? Has the translator been "faithful" or has she "betrayed" the original, that is, have scenes been suppressed, altered or changed in any way? Hence, suppression of source language material in the target language, I contend, is a useful way to support claims about which translation is to be viewed as better, where "better" is recognizably a subjective judgement.

In the course of this paper, I shall compare the Brazilian translation with the European Portuguese translation. I will attempt to point out in what instances either one of the translations would fit Robinson's ideal of "a physically tangible or emotionally alive TL text" (p. 17).

I accept the interpretations of the Catcher proposed by Bryan (1974) in his psychoanalytic reading of the novel and Rosen (1987) in his "sex as death" analysis; basing my argument on the views held by these authors, I want to argue here that instances of suppression that I have observed in the two translations do indeed detract from the original. I am not claiming that the original is sacred and that a prospective translator does not have the right to alter the original. Two thousand years of normative or traditional translation theory have conditioned translators and literary critics to believe that there has to be a literary, linguistic or aesthetic motive for making changes in the plot or in the narrative. I feel, however, that there must be some reason or motivation for "infidelity" on the part of translators. Translation is not "an anything goes" activity.

In order to make my point, I first of all intend to set out the main ideas of the critics mentioned above that are pertinent to my argument. Rosen (1987: 103) argues that the "hero" of the novel is afraid to enter the adult world, letting go of his childhood. Galloway (1987: 29) observes that it is not the case that Holden refuses to grow up; actually, he agonizes over the fact that he already is grown up. As Rosen sees it, Holden does not trust sex, for it represents "involvement in the world" and "the final entry into time" (p. 102). In Rosen's words:

Time is the medium in which change lives. Time is the silent partner of death and sex is the passageway through which one is seduced into entering time. (p. 102)

In Holden's mind, sex, in addition to being linked with time, is also connected with aggression, competition, and materialism - three characteristics of American culture that Holden detests. Rosen and Bryan argue that there is also a connection between sex and death for in American culture the same expression, fuck you, is employed in the culture "for its highest aggressive insult" and "for its term for sexual intercourse", (p. 103) as well. Rosen explains his view in the following lines:

In the culture's mind and in Holden's, sex is something men commit [Rosen's emphasis] on women and it is clear that this view of the culture's language and value system, has poisoned it for Holden. (p. 103)

I accept Rosen's concluding argument that Holden indeed equates sex with death. In this writer's words:

So we come full circle: Holden fears aggression because it may lead to death, sex is equated with aggression, and once again, sex is thus connected with death and its agent, the grim reaper Time. (p. 104)

Holden is obsessed with death and is not able to accept the reality of the death of his younger brother, Allie. Reminders of death are everywhere. In a museum near his sister's 
school, he finds the words fuck you written on the wall of the tombs of the Egyptian mummies. Holden imagines his own death and makes the following comment:

I think, even if I ever die, and they stick me in a cemetery, and I have a tombstone and all, it'll say "Holden Caulfield" on it, and then what year I was born and what year I died and then right under that it'll say "fuck you". I'm positive in fact. (pgs. 210-211)

Rosen is of course wrong in claiming that the phrase fuck you with its dual use as an insult and as a reference to sexual intercourse is a characteristic limited only to American culture. The same dual meaning exists in British English and other varieties of the language. In addition, these two meanings exist in other Indo-European languages such as Spanish joder and Portuguese foder.

Rosen does, however, make an excellent point about the use of this expression in the novel. Salinger has his own literary creation, the main character of the novel, Holden Caulfield, act as censor, attempting to erase the expression on the three occasions that he finds the word, twice in his sister's school (pgs. 207-208) and once in the mummy room of the Museum of Natural History, (p. 125). While Holden is quite liberal in his use of words like goddam, chrissake, bastard, sonuvabitch, and even tells his date, Sally Hayes, that she gave him a royal pain in the ass (p. 139) he never uses the expression fuck you or related forms in his conversations with the people he meets. But Salinger, the author, is insisting that the word not be censored. Holden is the censor or "The Catcher" who tries to prevent young children from learning about sex and aggression. According to Rosen:

...Salinger, by including [Rosen's emphasis] these fuck you signs, is actually scrawling them on the walls of his book, forcing the reader to acknowledge their presence and deal with them. (p. 105)

Rosen concludes that Salinger is not at all playing the role of "Catcher"; on the contrary, he is urging the reader "to grow up and accept the fallen world in which he finds himself" (p. 105). Those who censored the novel and removed it from reading lists and libraries are doing what Holden was trying to do, that is, to hide the reality of life, to hide sex away and not face the world as it is. Rosen (p. 105) also points out that Salinger himself faced censorship on the part of the New Yorker for the editors objected to Holden's language and, as a result, the inscription fuck you did not appear in a Holden Caulfield story published by this magazine in 1946 five years before the publication of the novel.

If The Catcher in the Rye in its own country of origin met with censorship, it is no wonder then that outside the USA, this novel caused controversy and instigated the censors to use their pens to strike out terms or adjust scenes deemed offensive to a specific community of readers.

One does not have to look too far to find censorship, for a comparison of the American version published by Little, Brown (shown in 1 below) with the British edition published by Hamish Hamilton (in 2 below) indicates that the latter has simply censored the language of the former substituting a dash (-) for the four letters of the word.

(1) (a) "I saw something that drove me crazy. Somebody'd written "fuck you" on the wall." (Little, Brown and Company, p. 201).

(b) "I went down by a different staircase and I saw another "fuck you" on the wall." (Little, Brown and Company, p. 202).

(2) (a) "I saw something that drove me crazy. Somebody'd written "- you" on the wall." (Hamish Hamilton, p. 207).

(b) "I went down by a different staircase and I saw another " - you" on the wall." (Hamish Hamilton, p. 208). 
There is an element of magic in language for all of us. If the word is not written out completely, then it has not really been used, and people are, therefore, not upset. This is probably why the British editors did not write the four letters of the word. It was not until the 1994 edition that Hamish Hamilton in collaboration with Penguin Books reproduced for the first time "... the original American text."

In order to facilitate a comparison of the two translations, I will identify the Brazilian Portuguese translation of Alencar, Rocha and Dauster with the initials (BP) and the Continental or European Portuguese of Palma-Ferreira with (EP).

With respect to the words fuck you, the BP translators provide an appropriate equivalent, foda-se (shown in 3) while the EP translator renders this inscription as vai à merda (in 4) which can be glossed as "go to the shit" or literally "go shit":

(3) "... vi uma coisa que me deixou maluco de raiva. Alguém tinha escrito "foda-se" na parede" (BP, p. 174)

(4) "... vi uma coisa que me deixou varado. Alguém escrevera na parede: "vai à merda" (EP, p. 223)

I contend that the EP translation in (4) is not felicitous. I predicate my argument on the acceptance of Rosen's analysis of Holden's trauma caused by the death of his younger brother and his personal difficulty in finding meaning in his own life.

The choice of vai à merda does not fit the situation for there is nothing in the expression that would awaken particularly his sister, Phoebe, and other children to the knowledge of sex. Also, the expression vai à merda ("go shit") would not drive Holden crazy. Bryan (1974: 1068) observes that Holden is scandalized not by the obscene inscription fuck you but by the "obscenity", in Holden's mind, of the sexual act itself.

There is another argument for considering the EP expression vai à merda inappropriate in this particular context. Holden sees the word three times and each time he becomes quite incensed. On the second occasion that he encounters the word, he finds that it is impossible to remove for it was scratched on the surface of the wall and could not be erased. This is significant, for no censorship can erase the realities of life (birth, childhood, adulthood, senility and death). The challenges and problems of life must be faced. Salinger is saying that there are things that cannot be hidden. In Holden's mind sex is equated with sin. The role of sex in life has to be brought out into the open. Holden is afraid of "dirty kids" who will present what he sees as "cockeyed" (p. 208). Salinger is objecting to a society that is hypocritical about sex. Dialogue and interaction with other people were two things that Holden was looking for but could not find.

One of the most poignant moments in the novel is the family scene that emphasizes Holden's loneliness in contrast with: "This family that you could tell just came out of some church were walking right in front of me - a father, a mother and a little kid about six years old." (p. 121). Holden goes on to describe the little boy:

"This kid was swell. He was walking in the street, instead of on the sidewalk, but right next to the kerb. He was making out like he was walking a very straight line, the way kids do, and the whole time he kept singing and humming. I got up closer so I could hear what he was saying. He was singing that song, "If a body catch a body coming through the rye." (pgs. 121-122)

Holden evaluates the situation and states that the little boy's singing contributed to making him "feel not so depressed any more" (p. 122). What Holden needed most and did not have was an emotionally supportive relationship with his parents. His father is mentioned but never appears in the narrative. His mother appears only once in a late-night visit to her daughter's room to inquire why she was not asleep. Quite ironically, Holden was 
hiding in his sister's closet while his mother talked with Phoebe. Later on in this presentation, I intend to discuss this bedroom scene or, in Bryan's terms, "the mock romance".

Let me examine at this point the title of the novel. The BP translators, Alencar, Rocha and Dauster, in an introductory note, state that it was their desire to translate the title as A Sentinela do Abismo (The Sentinel of the Abyss), but Salinger did not accept this title and insisted on the supposedly more "faithful" literal translation of the original, $O$ Apanhador no Campo de Centeio. (The Catcher in the Rye). I feel that the title Salinger rejected would have been a more appropriate one for the Brazilian public than The Catcher in the Rye which is language-and culture-specific based on the poem by Robert Burns.

Many Brazilian readers would probably not be familiar with this poem by Burns and no doubt these readers would have some difficulty in understanding how a young man of Holden's age who demonstrated no athletic prowess at all could be strong enough to prevent children from falling into an abyss near a field of rye where they were playing. Observant readers will no doubt remember that Holden says that he "...can't make a real fist any more - not a tight one..." (p. 42) and, he remarks, on two occasions, (p. 9 and p. 13 respectively) that he has no wind, and therefore cannot participate in sports.

Holden's comment on his role in life is, most likely, the motivation for the Brazilian translators' wish to entitle the novel A Sentinela do Abismo ("The Sentinel of the Abyss").

Thousands of little kids, and nobody's around - nobody big, I mean - except me. And I'm standing on the edge of some crazy cliff. What I have to do, I have to catch everybody if they start to go over the cliff — I mean if they're running and don't look where they're going I have to come out from somewhere and catch them [Holden's emphasis]. That's all I'd do all day. I'd just be the catcher in the rye and all. I know it's crazy, but that's the only thing I'd really like to be. I know it's crazy. (pgs. 179-180)

Salinger's refusal to allow the translators freedom to choose a title that, in their judgement, captured the spirit of the novel characterizes a view of translation in which the author and his original are considered sacred.

Even though the Brazilian translators were thwarted in their desire to propose a title that was more meaningful to them, they were able to maintain the words "a sentinela no abismo" in the body of the text. In most cases, all-powerful authors do not read the TL text. Not knowing Portuguese, Salinger was not in a position to comment on the "faithfulness" of the translation. So some translational deviation or a bit of subversion was possible. Subversion in translation occurs more than one would think. For example, Robinson (1991: 225) points to Nida's "subversive" participation in the translation of Today's English Version of the Bible where Jesus is presented as "the boy next door, everybody's pal" who speaks like all of us in our own language and dialect.

In the passage below, I compare the original English of The Catcher (shown in 5) with the BP translation in (6):

(5) I'd just be the catcher in the rye and all. I know it's crazy, but that's the only thing I'd really like to be. I know it's crazy. (p. 181)

(6) Ia ser só o sentinela do abismo e tudo. Sei que é maluquice, mas é a única coisa que eu queria fazer. Sei que é maluquice. (BP, p. 151) (my emphasis)

Observe that in the bold type portion in (6) the translators were "unfaithful" to the original. They indulged in an act of subversion or "disobedience". When Salinger rejected the title, they just left the words "the sentinel of the abyss" where it was. This is not at all the case with the EP translator, Palma-Ferreira. He does not subvert, as the Brazilian translators do, this specific scene in which Holden tells his sister that he would like to protect little children from falling over the cliff by being "the catcher in the rye" or "the sentinel of 
the abyss". For the EP translator, "the catcher in the rye" is rendered "o vigia do campo de centeio", (p. 196), literally, "the watchman of the field of rye".

I think the image of the abyss is important to the understanding of this novel. Holden is in no physical or emotional condition to save children from falling off precipices. It is ironic that Holden considers himself the one responsible for preventing children from falling off cliffs for he is the who is in danger of "falling into an abyss", that is, who is on the brink of a nervous breakdown. It is important, also, to remember that Holden is telling his story, in his words, "this madman stuff" (p. 5) from a psychiatric ward of a hospital in California because he "got pretty rundown and had to come out here and take it easy" (p. 5). Holden is obsessed with falling. The fall represents his depressed state, on one hand, his fear of falling from favor (no one understands him or loves him), and, on the other, his fear of falling into sin, that is entering into the "corrupt" adult world.

The suggestion of the title A Sentinela do Abismo ("The Sentinel of the Abyss") for the BP version and the use of these words in the narrative in replacement of the original The Catcher in the Rye is well-motivated. When Holden visits his former teacher, Mr. Antolini, he is once again reminded of a possible fall. This teacher predicts that Holden is headed for a fall, "... a special kind of fall, a horrible kind. The man falling isn't permitted to feel or hear himself hit the bottom" (p. 194). Antolini sees Holden as "... dying nobly one way or another, for some highly unworthy cause" (p. 195). When queried by his sister about what he wants to do with his life, Holden answers that he wants to be the "catcher in the rye." This idea occurred to Holden while he was eavesdropping on a little boy who was walking on a sidewalk near the curb singing "if a body catch a body coming through the rye." (p. 121) How different are the situations of the little boy and Holden. The former is on the edge of a curb singing this song while Holden wants to place himself on the brink of an abyss to save little children from the dangers of life. He states earlier on his narration that the self-inflicted injury to his hand will prevent him from being a surgeon or a violinist (p. 42). His sister's question is quite devastating to Holden, for he is, throughout the novel, concerned about the meaning of life and what role he should or should not play in it. He answers Phoebe that he is not good at Science to be a scientist, and his remarks about becoming a lawyer reveal his basic fear — of becoming a phoney, of selling himself in some way, as his elder brother D.B. did by writing material for the Hollywood motion picture industry.

In the case of the title of the EP translation, Palma-Ferreira simply states that Uma Agulha no Palheiro ("A Needle in the Haystack") was selected because of the expressiveness of this well-known Portuguese saying. He hastens to remark that this title is faithful to what Salinger intended and will mark the spirit of the book, whatever this may mean. It would indeed be interesting to know why the EP translator was permitted to furnish a different title while the BP translators were not.

One could argue that Uma Agulha no Palheiro ("A Needle in the Haystack") is an adequate title, for Holden Caulfied is indeed a questor who is in search of something or, no doubt, somebody who might understand him and see what he sees, and, presumably, this person will be hard to find. Holden's teacher, Mr. Antolini tries to help him find a way out of his crisis. I cite part of Antolini's advice to Holden below:

The whole arrangement's designed for men, who, at some time or other in their lives, were looking for something their own environment couldn't supply them with. Or they thought their own environment couldn't supply them with. So they gave up looking. They gave it up before they ever really even got started. You follow me? (p. 194)

Perhaps a reading of this specific passage on the part of the EP translator was his motivation, in whole or in part, to entitle the novel Uma Agulha no Palheiro ("A Needle in 
the Haystack"). But Palma-Ferreira does not use this title at all in the body of his translation. He might, for example, have rewritten the scene and have had Antolini chide Holden about "looking for a needle in the haystack". This is, no doubt, an unfair criticism of Palma-Ferreira for at the time this translation was published, it was unthinkable for translators to alter the original text.

I would like to turn now to some of the scenes in the novel in order to see how they are presented in the respective translations. Do characters change personality? Do angels become devils? Do we have three different Holden Caulfields, a Brazilian and a Portuguese one, in addition to the native New Yorker? ${ }^{3}$ The answer to these questions is a definite "no". The four translators can either be praised for being "faithful" by those who value faithfulness or condemned for being "subservient" by those who advocate rebellion and independent thinking.

While no drastic changes occur in the plot of the original, some of the scenes, episodes or moments undergo subtle changes; in some cases these changes are rather serious but could be resolved by recourse to a bilingual dictionary. Other alterations, however, are more serious for they reveal a desire to "clean up" the original, to dress up the translation so it will not offend potential readers. Let us look first at cases where a dictionary could help improve the translation.

It appears that both the BP and EP translators respectively consider a "soul kiss" to be um beijinho ("a little kiss") or merely um beijo ("a kiss"). Holden's intention was to provoke his date, Sally Hayes with whom he had a love-hate relationship. On one hand, he was sexually attracted to her and enjoyed caressing her in taxis, but on the other hand, he was repulsed by her shallowness and hypocrisy. By simply telling her to kiss an acquaintance she met at a theater during the intermission of a play he would not irritate her. But by telling her to give this acquaintance of hers a "soul kiss", Holden reveals his aggression and annoyance with Sally Hayes. This is indeed a case of loss in translation and one that could be avoided had a dictionary been consulted or had the translators queried native speakers or resorted to informed non-natives. ${ }^{4}$ Sally Hayes is indeed a problem for Holden. On a date with her, he declares that he felt like marrying her and asks her to run away with him. But he also complained that she is a phoney and very stupid with a very loud, embarrassing voice (p. 190). He also disliked this girl's mother as well for her pride and snobbishness irritated him. On the other hand, he was quite impressed with the humility of two nuns who, with a basket in hand, would collect money on the streets of New York. They were the antithesis of Sally Hayes' mother. I set out Holden's remarks in the original in (7) followed by the BP and EP versions, respectively (8) and (9).

(7) And old Sally Hayes' mother. Jesus Christ. The only way she [Salinger's emphasis] could go around with a basket collecting dough would be if everybody kissed her ass for her when they made a contribution. (p. 120)

(8) E a mãe de Sally Hayes! Puxa vida. Só via um jeito dela sair recolhendo dinheiro numa cesta; era se todo mundo ainda tivesse que fazer a maior reverência, se dobrar até o chão, cada vez que entregasse um donativo. (BP, p. 103)

(9) E a mãe de Sally Hayes! Só consentiria em fazer um peditório com um cesto de Natal se em paga lhe beijassem o rabo! (EP, p. 133)

Holden's shows his annoyance with Sally Hayes's mother with his extremely hostile and vulgar remarks in bold type in (7). The BP translators, unfortunately, raise the register of the original employing formal language, thereby changing Holden's attitude and behavior "showing great reverence by bowing to the ground in deference" (my translation). This rather serious loss in translation contributes to weakening the force of Holden's feelings and is not all consistent with other instances of irritation on Holden's part with Sally, her 
mother or other people he considers to be "phonies." Perhaps the Brazilian translators felt that Holden's remarks in translation would indeed offend their reader's sensibilities. Or perhaps their own personal sensibilities influenced their choice of register. When three different translators work together on a translation, there is always a danger that individual preferences or prejudices with respect to style and register creep into their undertaking.

The EP version in (9), however, is a satisfactory translation of the original in (7) for the vulgarity and irreverence of "if everybody kissed her ass for her" (p. 120) is rendered adequately with the words "...se em paga lhe beijassem o rabo" (p. 133).

Another example of loss occurs in the translation of the text of Holden's visit to his history teacher, Mr. Spencer, in order to say good-bye before leaving for New York. Holden states that his teacher criticized his written examination and handled it "...like it was a turd or something" (p. 16). The BP translators render turd in Portuguese as titica ("chicken shit") where bosta would be more appropriate - "Pegou na prova como se fosse titica ou coisa que valha" (p. 17); worse still the EP translators eschew any reference to excrement - "Começou a mirar e remirar a prova" (p. 20), ("he kept looking and looking at my paper").

The chapel scene is extremely important for the development of Holden Caulfield's impatience with hypocrisy, righteousness and materialism. An affluent alumnus named Ossenberger, "...who made a pot of dough in the undertaking business" (p. 20), gives a speech on Sunday morning in the school chapel. Holden objects to Ossenberger's false religiosity:

He said he [Holden's emphasis] talked to Jesus all the time when he was driving his car. That killed me. I can just see the big phoney bastard shifting into first gear and asking Jesus to send him a few more stiffs.

During Ossenberger's talk one of the students breaks wind, an act which causes much consternation among the faculty and staff and earns all the students a general reprimand from the headmaster at a compulsory study hall on the following evening. Let me present, first of all, the original text in (10) below followed respectively by the BP and EP translations in (11) and (12):

(10) "...then all of a sudden this guy sitting in the row in front of me, Edgar Marsella, laid this terrible fart. It was a very crude thing to do, in chapel and all, but it was also quite amusing." (p. 21)

(11) "...quando, de repente, um cara que estava sentado na minha frente, o Edgar Marsella, soltou um peido infernal. Era o tipo da coisa grosseira de se fazer numa capela e tudo, mas foi um bocado engraçado" (BP, p. 22)

(12) "...quando, de súbito, o rapaz que estava sentado mesmo na minha frente, Edgar Marsella, deu um tremendo arroto. Foi uma coisa horrível, ali na capela, mas, mesmo assim, foi divertido." (EP, p. 26)

The BP translator renders the vulgar "laid this terrible fart" (p. 21) of the original version with the equally vulgar and equivalent soltou um peido infernal (p. 22). But the EP translator suppresses all references to flatulence or breaking wind, substituting in its stead um tremendo arroto ("a tremendous belch"). No doubt Palma-Ferreira avoided an equivalent translation of fart in Portuguese in order not to offend his readers, his editor, and publisher. The substitution of belch for fart is also unfortunate, for in normal circumstances, a belch is involuntary whereas the breaking of wind, in the context of a hostile audience composed of students, can only be interpreted as an intentional act to ridicule and provoke the speaker. The substitution of belch for fart also contributes to the loss of the irreverent humor of this scene. 
The bedroom scene or "mock romance" is an important one in the novel for the understanding of Holden's problems. Bryan (1974) presents a psychoanalytic reading and observes that Holden gives his readers little information "on the event that may have brought on the trauma behind all his problems: The death of a younger brother when Holden was thirteen" (p. 1065). But Holden is indeed an excellent example of a self-conscious narrator who is aware of himself as a writer and even as a speaker (Booth 1968: 88, 96). Indeed, he provides a great deal of information about his love life, informing his readers that he "...can never really get sexy — I mean really sexy with a girl I don't like a lot" (p. 153) (Holden's emphasis). But there are unconscious feelings and emotions that Holden cannot reveal. Bryan argues that Holden's difficult relationship with women, particularly Sally Hayes, his aggressive behavior with everyone in general, and his fascination with death are due to his unresolved feelings for Phoebe. Throughout the novel, Holden is struggling with himself to keep these thoughts repressed. The "mock romance" occurs when Holden pays a surprise visit to his sister at their parents' home to say goodbye for he fears he is going to die suddenly. Bryan points out certain attitudes and actions that point to an unconscious struggle within Holden with regard to his sister. In the "mock romance" scene, Bryan (1974: 1072) points to some very revealing actions on Holden's part with respect to Phoebe: his pinching of her buttocks, their dancing together, and even the language he uses at the end of their encounter such as: keep in touch with her, she said I could sleep with her, she didn't want to take it, but I made her.

At the end of this scene, there is a final signal given to Holden. Phoebe informs Holden that she is taking belching lessons and asks him to listen. This detail is significant for Holden is reminded that Phoebe, although quite mature for her age, is a child, and he must struggle to renounce his designs on his sister.

The EP translator substitutes "singing" for "belching lessons". Compare the original in (13) with the BP and EP translations in (14) and (15) respectively:

(13) I'm taking belching lessons from this girl, Phyllis Margulies, she said. (p. 180)

(14) Tem uma colega minha, a Phyllis Margulies que está me ensinando a arrotar. (BP, p. 152)

(15) Agora tenho lições de canto com a Miss Phyllis Margilies (BP, p. 196) (The EP translator changed the spelling of the surname).

The substitution of "singing lessons" removes an important signal to Holden about his sister. She is a child and can never be the object of his love. Bryan (1974: 1069) observes that a sister frequently replaces the mother as love object, "...and that normal maturation guides the boy from sister to other women." In short, there is no motivation for substituting the word belching, the very same word the EP translator used to avoid the word fart in the chapel scene.

At this point, I should like to summarize before drawing some conclusions about my remarks. I have taken the EP translator to task for (i) suppressing the word fuck you substituting vai à merda ("go shit"), (ii) not incorporating the title Uma Agulha no Palheiro into at least one of the scenes, (iii) substituting um tremendo arroto ("a tremendous belch") for a terrible fart, and (iv) substituting lições de canto ("singing lessons") for belching lessons. On the other hand, I have criticized both the BP translators for translating turd as titica ("chicken shit") and the EP translator for avoiding the problem completely, and finally, (v) I have faulted, on one hand, the BP translators for the unmotivated raising of the register of Holden's remarks about Sally Hayes' mother, and on the other, have credited the EP translation for maintaining the vulgar language of the original.

This comparison of the two translations leads me to conclude that the BP translation is "better" or more felicitous than the EP one for the latter tends to disfigure important 
scenes and to suppress a number of instances of vulgar language in English where an equivalent Portuguese word in register could easily have been supplied. The Catcher in the Rye has been hailed as one of the most humorous works of American Literature. The substitution of belch for fart in the chapel scene removes an important instance of humor of the original.

One could ask if the suppression of vulgar for more polite language makes any difference in the case of Lusophone readers who do not read English. How would these readers know if vai à merda ("go shit") is satisfactory or not? I feel that the perceptive reader would indeed be at a loss to see how these words could invite questions about human sexuality.

The EP translator should have taken into consideration what Holden says after (my emphasis) the fuck you inscription. He informs his reader why he finds the word objectionable:

"I thought how Phoebe and all the other little kids would see it, and how they'd wonder what the hell it meant, and some dirty kid would tell them - all cockeyed naturally — what it meant, and how they'd all think about it and maybe even worry about it for a couple of days." (p. 207)

In short, there is nothing about the expression vai à merda (go shit) that would lead young children to inquire about the meaning and to receive "misinformation" about the facts of life from some prurient teenager.

The BP translation comes closer, I feel, to Robinson's view of "... generating a physically tangible or emotionally alive TL (target language) text" (p. 17). The BP translators in general come to grips with the vulgar language of the original without resorting to suppression. In addition, the BP translators contribute, in my mind, to the improvement of the original in their "subversive" substitution of "the sentinel of the abyss" for "the catcher in the rye". With respect to this bit of subversion at least, the BP translators approach Robinson's (1991: 19) view of the ideal translation that returns "... to the original as much as it took from it." According to Rabassa (1981: 1), a translation cannot approach an original, but it can be considered "good" or "bad", depending on how closely or accurately it approaches the original. I disagree partially with Rabassa for I feel the translator can make changes that can actually approach or improve the original and that is what the BP translators tried to do in their desire to change the title and in their actual use of "the sentinel of the abyss" in their text. For Barnstone (1993: 260), the translator must betray the letter so as to be faithful "...to the meaning, art, spirit of the source text." 5

Both translations need, as I have tried to show, to be revised. Perhaps the moment is propitious for the publications of new translation in each variety of Portuguese.

The comparison of the two translations herein leads me to suggest that translators read, before setting out to translate, some of the criticism about the author they are planning to translate. Had the four translators read some of the published comments on Salinger's work, they, no doubt, would have produced more satisfactory and pleasing translations for themselves and their readers. As Barnstone (1993: 12) states, "...good translation is good literature, it is not distinguished because of its race."

The final point I would like to make is obvious considering what I have said about the suppression of references to sex and body functions: translators should indeed be faithful to the vulgarity and obscenity they encounter in their day-to-day contact with texts to be translated. Those translators that censure the language of the texts they are working on are like Holden Caulfields who try to protect people by erasing what they judge as objectionable. 


\section{Notes}

1. I would like to thank the following colleagues who read and made comments about this paper: Carlos Daghlian, JoAnne Busnardo, Antonio Arnoni Prado and Eric Sabinson. I also want to thank Douglas Robinson for his critical remarks and stylistic suggestions. I assume complete responsibility for the shortcomings of this paper. I am also grateful to the Fundação de Amparo à Pesquisa do Estado de São Paulo-FAPESP for a travel grant (96/ 2321-1) to present this paper at the AUETSA'96 Conference (June 30-July 5, 1996) at the University of the Western Cape, Cape Town, Republic of South Africa.

2. Throughout this paper, I will use the 1982 Hamish Hamilton edition of the novel for quotations. The British edition, in addition to substituting a dash for the inscription fuck you, employs British spelling in words such as curb/kerb, ax/axe.

3. For a different view, consult Giana Maria Gandini Giani (1992), "A Tradução como Diferença: Um Estudo sobre: The Catcher in the Rye, O Apanhador no Campo de Centeio e Uma Agulha no Palheiro, unpublished MA thesis, Universidade Estadual de Campinas, S.P.

4. Possible translations for "soul kiss" in Portuguese might be beijo de língua or beijo profundo. I do not mean to suggest that dicitionaries are sacred and the only option for translators in their work. I agree with Robinson's (1991: 8) remark: "Neither the dictionary nor the thesaurus nor any formalization of semantic fields holds sway over the volatility of actual speech use." Barnstone's (1993: 116-117) "Eighteen Quick Looks at the Translator's Dictionaries or a Guide to Guides of Truth and Error" show the strengths and weaknesses of monolingual and bilingual dictionaries.

5. One criticism that might be leveled against my arguments in this paper is that I am considering interpretation as the core of literary analysis and not looking at the role of power and ideology in translation. The rewritings vai à merda ("go shit"), arroto ("belch") in the European Portuguese translation manipulate, or better still, suppress the incipient counter-culture ideology of the late fifties and early sixties in the USA (Danesi 1994), characterized by authentic teen-age language replete with the use of vulgar language as protest against the power structure of the conservative and hypocritical adult world. For a different view, consult André Lefevere (1992).

\section{REFERENCES}

BARNSTONE, Willis (1993): The Poetics of Translation: History, Theory, Practice, New Haven, Yale University Press.

BIGUENET, John \& Rimer SCHULTE (Eds) (1989): The Craft of Translation, Chicago, The University of Chicago Press.

BOOTH, Wayne C. (1967): "Distance and Point-of-View: An Essay in Classification", Philip Stevick (Ed.), The Theory of the Novel, New York, The Free Press.

BRYAN, James (1974): "The Psychological Structure of The Catcher in the Rye", PMLA, 89 (5), pp. 1065-1074.

CHUTE, B. J. (1971): "The Necessity of Translation", Papers Delivered at the Conference on Literary Translation, (May 1970), New York, Pen American Center.

COSTELlO, Donald P. (1959): "The Language of The Catcher in the Rye", American Speech, 34 (3) (Oct.), pp. 172-181.

DANESI, Marcel (1994): Cool: The Signs and Meanings of Adolescence, Toronto, University of Toronto Press.

GALLOWAY, David D. (1987): "The Love Ethic", Harold Bloom (Ed.), J.D. Salinger, New York, Chelsea House Publishers.

GRESS, Elsa. (1971): "The Art of Translating", Papers Delivered at the Conference on Literary Translation, (May 1970), New York, Pen American Center.

LEFEVERE, André (1992): Translation, Rewriting and the Manipulation of the Literary Fame, Routledge, London.

RABASSA, Gregory (1989): "No Two Snowflakes are Alike: Translation as Metaphor", J. Biguenet and R. Schulte (Eds.), The Craft of Translation, Chicago, The University of Chicago Press.

ROBINSON, Douglas (1991): The Translator's Turn, Baltimore, The John Hopkins University Press.

ROSEN, Gerald (1987): "A Retrospective Look at The Catcher in the Rye", Harold Bloom (Ed.), J. D. Salinger, New York, Chelsea House Publishers.

SABINSON, Eric Mitchell (1991): "On the Translation of Sex", Ruth Gabriela Kirstein, The Body and Sexual Politics in Modern Latin America Fiction, Paunch, 65-66, 1-10.

SALINGER, Jerome D. (1982) [1951]: The Catcher in the Rye, Harmondsworth, Penguin Books.

SALINGER, Jerome D. (1991) [1951]: The Catcher in the Rye, Boston, Little, Brown and Company.

SALINGER, Jerome D. (1994) [1951]: The Catcher in the Rye.

SALINGER, Jerome D. (1965) [1967]: O Apanhador no Campo de Centeio, 4th edition (translated by Álvaro Alencar, Antônio Rocha, Jório Dauster), Rio de Janeiro, Editora do Autor.

SALINGER, Jerome D. (sine data): Uma Agulha no Palheiro, (translated by João Palma-Ferreira), Lisboa, Edição "Livros do Brasil".

STEVICK, Philip (1967): The Theory of the Novel, New York, The Free Press. 